\title{
Peptide mapping and characterisation of glycation patterns of the glima 38 antigen recognised by autoantibodies in Type I diabetic patients
}

\author{
U.Roll ${ }^{1}$, C. W. Turck ${ }^{2}$, S. E. Gitelman ${ }^{3}$, S.M. Rosenthal ${ }^{3}$, M.S. Nolte ${ }^{4}$, U.Masharani ${ }^{4}$, A.-G. Ziegler ${ }^{5}$, S. Baekkeskov ${ }^{1}$ \\ ${ }^{1}$ Departments of Medicine and Microbiology/Immunology, Hormone Research Institute, University of California San Francisco, \\ USA \\ ${ }^{2}$ Howard Hughes Medical Institute, Department of Medicine and Cardiovascular Research Institute, University of California San \\ Francisco, USA \\ ${ }^{3}$ Department of Pediatrics, University of California San Francisco, USA \\ ${ }^{4}$ Department of Medicine, University of California San Francisco, USA \\ ${ }^{5}$ Diabetes Research Institute and Third Medical Department City Hospital Schwabing, Munich, Germany
}

\section{Abstract}

Aims/hypothesis. Glima 38 is an $N$-glycated neuroendocrine membrane protein of $\mathrm{M}_{\mathrm{r}} 38000$, which is recognised by autoantibodies in approximately $20 \%$ of patients with Type I (insulin-dependent) diabetes mellitus. The aim of this study was to characterise the carbohydrate moiety and generate peptide maps of glima 38.

Methods. Sera of high immunoreactivity to glima 38 were used to isolate $35-\mathrm{S}$ methionine-labelled protein from $\beta$ TC- 3 cells and a neuronal cell line GT1.7. Tunicamycin was used to inhibit $N$-glycation of glima 38 and define the core protein. The carbohydrate moiety was characterised for tunicamycin sensitivity, lectin binding and susceptibility to different endoglycosidases. The protein moiety was subjected to digestion by proteases to define peptide maps.

Results. The autoreactive epitopes in glima 38 recognised by Type I diabetic sera are conformational and independent of the carbohydrate moiety. Inhibition of $N$-glycation of glima 38 in vivo, shows a protein core of $\mathrm{M}_{\mathrm{r}} 22000$ in both pancreatic $\beta$ - $(\beta \mathrm{TC} 3)$ and neuronal (GT1.7) cell lines. The carbohydrate moieties in the two cell types are distinct but contain a similar amount of terminal sialic acid residues and at least five oligosaccharide chains Glima 38 binds Triticum vulgare and Ricinus communis I lectins. Endoproteinase treatment of the $\mathrm{M}_{\mathrm{r}} 22000$ core protein results in peptides of $M_{r} 4500$ and $M_{r} 20000$ with Lys-C, and peptides of $M_{r} 4000$ and $M_{r} 11000-12000$ with Glu-C/V8 and Asp-N proteases.

Conclusion/interpretation. The biochemical properties of glima 38 define it as a new autoantigen in Type I diabetes and provide a basis for its purification. [Diabetologia (2000) 43: 598-608]

Keywords Type I diabetes, immunology, autoantibodies, target autoantigen, $38000 \mathrm{M}_{\mathrm{r}}$ autoantigen, glima 38, proteolytic cleavage, peptide mapping, lectin binding, deglycation.
Type I (insulin-dependent) diabetes mellitus is a chronic autoimmune disease, where the rapid onset is often preceded by a long prediabetic phase [1].

Received: 18 October 1999 and in revised form: 29 December 1999

Corresponding author: S. Baekkeskov, $\mathrm{PhD}$, Hormone Research Institute, University of California San Francisco, 513 Parnassus Avenue, Room HSW 1090, San Francisco, CA 94143-0534, USA

Abbreviations: ConA, Concanavalin A from Canavalia ensiformis; GADA, antibodies to GAD65; glima 38; glycated islet cell membrane antigen of $38000 \mathrm{M}_{\mathrm{r}}$; IA-2A, antibodies to IA-2ic;
The gradual destruction of insulin-producing beta cells is accompanied by circulating autoantibodies to various islet cell antigens. Antibodies to islet cells

IAA, insulin autoantibodies; ICA, islet cell antibodies; IgG; immunoglobulin G; LcH, lectil lentin from Lens culinaris, LEA, Lycopersicon esculentum lectin; MAA, Maackia amurensis lectin; NHS, normal human serum; PAS, protein A Sepharose; PFAP, particulate fraction, aqueous phase; PFDP; particulate fraction, detergent phase; PNA, Arachis hypogaea lectin; RCA-I, Ricinus communis lectin I; TBS, TRIS-buffered saline; TBST, TBS $/ 0.01 \%$ Tween 20; UEA, Ulex europaeus lectin; WGA, wheat germ agglutinin. 
(ICA), made visible by immunofluorescence on frozen sections of human pancreas, are observed in $60-90 \%$ of patients with newly diagnosed Type I diabetes and can react to one or more beta-cell antigens [2]. Thus, antibodies to glutamic acid decarboxylase, GAD65, [3] are present in 70-80\% $[4,5]$ and antibodies to a putative tyrosine phosphatase IA-2 [6-8] are present in $60-70 \%$ of newly diagnosed Type I diabetic and prediabetic patients [5, 9]. Autoantibodies to both GAD65 and IA-2 immunoprecipitate their target antigen from lysates of islet cells in contrast to autoantibodies to insulin [10], which are present in $16-70 \%$ of newly diagnosed Type I diabetic patients [2].

We have identified a third islet autoantigen, glima 38, which is immunoprecipitated by autoantibodies in sera from a subset of Type I diabetic patients [4]. Glima 38 is an amphiphilic N-Asp glycated beta-cell membrane protein, expressed in islets and in islet and neuronal cell lines [4]. Several other proteins of a relative molecular mass $\left(\mathrm{M}_{\mathrm{r}}\right)$ of 38000 have been implicated as autoantigens in Type I diabetes [11-15, 4]. Some of these molecules have been identified. A $M_{r} 38000$ rat insulinoma protein was described to be the target of a $\mathrm{CD} 4^{+} \mathrm{T}$ cell clone derived from a Type I diabetic patient [11]. This protein was sequenced and named imogen 38 [15]. Imogen 38 is not N-Asp glycated, has a wider tissue distribution than glima 38 and does not seem to be a target of humoral immune response in Type I diabetes [15]. Antibodies to a second $\mathrm{M}_{\mathrm{r}}$ 38000 protein, the nuclear transcription factor jun$\mathrm{B}$, were detected in newly diagnosed Type I diabetic patients. In contrast to glima 38 , jun-B is a non-glycated, soluble nuclear protein [13]. Thus both imogen 38 and jun $\mathrm{B}$ are distinct from glima 38 [4]. In an animal model of Type I diabetes, the $B B$ rat, antibodies to yet another protein of $\mathrm{M}_{\mathrm{r}} 38000$ have been described $[14,16]$.

The aim of this study was to test whether glima 38 is recognised by $B B$-rat autoantibodies to a 38000 $\mathrm{M}_{\mathrm{r}}$ protein and to characterise its glycation and proteolytic degradation patterns.

\section{Subjects and methods}

Antisera. Patients with Type I diabetes were from the Adult and Pediatric Diabetes Practices at the University of California San Francisco and the Third Medical Department, City Hospital Schwabing, Munich. Type I diabetes was diagnosed according to World Health Organisation criteria [17]. Diabetes was classified as Type I (insulin-dependent) on the basis of clinical presentation, including lean body habitus, lack of acanthosis nigricans, presence of diabetic ketoacidosis, low or absent serum insulin or $\mathrm{C}$ peptide and/or presence of islet cell autoantibodies. Sera were obtained after informed consent from 44 patients with Type I diabetes at clinical onset or within 6 months of diagnosis (mean age \pm SD: $22.2 \pm 14.6$ years; range: $1-54$ years; median 17 years). Sera of two first-degree
Table 1. Glima 38 antibody-positive subjects identified amongst 44 newly diagnosed Type I diabetic patients and first-degree relatives of Type I diabetic patients

\begin{tabular}{|c|c|c|c|c|c|c|}
\hline Patient & $\begin{array}{l}\text { Serum } \\
\text { no. }\end{array}$ & $\operatorname{sex}$ & $\begin{array}{l}\text { age } \\
\text { (years) }\end{array}$ & $\begin{array}{l}\text { GAD65 } \\
\text { anti- } \\
\text { bodies }\end{array}$ & $\begin{array}{l}\text { IA-2ic } \\
\text { anti- } \\
\text { bodies }\end{array}$ & $\begin{array}{l}\text { glima } 38 \\
\text { anti- } \\
\text { bodies }\end{array}$ \\
\hline \multirow[t]{2}{*}{1} & U38 & f & 6 & neg & pos & pos \\
\hline & U63 & & 6.5 & neg & pos & neg \\
\hline 2 & U45 & $\mathrm{f}$ & 1 & pos & pos & pos \\
\hline 3 & U46 & $\mathrm{m}$ & 18 & neg & pos & pos \\
\hline \multirow[t]{2}{*}{4} & U47 & $\mathrm{m}$ & 14 & pos & pos & pos \\
\hline & U86 & & 14.6 & neg & pos & pos \\
\hline 5 & U53 & $\mathrm{f}$ & 26 & pos & pos & pos \\
\hline 6 & U55 & $\mathrm{m}$ & 10 & pos & pos & pos \\
\hline 7 & U56 & $\mathrm{m}$ & 42 & pos & pos & pos \\
\hline 8 & U70 & $\mathrm{m}$ & 8 & pos & pos & pos \\
\hline \multirow[t]{3}{*}{9} & U76 & $\mathrm{m}$ & $\mathrm{N} / \mathrm{A}^{\mathrm{a}}$ & pos & pos & pos \\
\hline & U77 & & $\mathrm{N} / \mathrm{A}^{\mathrm{a}}$ & pos & pos & pos \\
\hline & $\mathrm{U} 80^{\mathrm{b}}$ & & $\mathrm{N} / \mathrm{A}^{\mathrm{a}}$ & pos & pos & pos \\
\hline 10 & U87 & f & 2 & pos & pos & pos \\
\hline \multirow[t]{2}{*}{$11^{\mathrm{d}}$} & U9 & $\mathrm{f}$ & 11.5 & neg & neg & pos \\
\hline & U40 & & 12 & pos & neg & pos \\
\hline $12^{\mathrm{d}}$ & $\mathrm{U} 122^{\mathrm{c}}$ & f & 3 & neg & neg & pos \\
\hline
\end{tabular}

${ }^{\mathrm{a}} \mathrm{N} / \mathrm{A}=$ Not available; ${ }^{\mathrm{b}}$ purified $\mathrm{IgG}$ from plasma collected during plasmapheresis of patient 9 [18] 2 weeks after drawing of serum U76. Serum U77 was drawn at the time of plasmapheresis. ${ }^{\mathrm{c}}$ Progression of Type I diabetes 2 years after serum was collected. ${ }^{\mathrm{d}}$ ICA/IAA positive first-degree relatives of Type I diabetic patients

relatives of Type I diabetic patients (Table 1: U9 and U122) were also analysed. This study was approved by the Committee on Human Research at the University of California San Francisco.

Sera were screened for glima 38 antibodies, GAD65 antibodies (GADA) and IA-2ic antibodies (IA-2A) as described below. Follow-up sera were available for 4 of the glima 38 antibody positive subjects (Table 1: U38, U47, U76, U9). One of these patients (U76) underwent plasmapheresis and purified immunoglobulin $\mathrm{G}$ ( $\mathrm{IgG}$ ) from one treatment was used to prepare an immunoaffinity resin for glima 38 (Table 1: U80; [18]). The purified IgG fraction is positive for ICA, insulin autoantibodies IAA, GADA and IA-2A and has a concentration of $\mathrm{IgG}$ fivefold lower than in the patient's original serum sample (U76; data not shown).

We obtained five $B B$-rat sera positive and five $B B$-rat sera negative for antibodies to a rat membrane-bound islet cell-specific $38000 \mathrm{M}_{\mathrm{r}}$ autoantigen [14, 16] from Dr. Yoon, University of Alberta, Calgary and tested for the presence of antibodies to glima 38 as described below.

Preparation of cell extracts enriched in glima 38. The murine pancreatic insulinoma $\beta$ TC3 cell line [19], a gift from Dr D. Hanahan, University of California San Francisco, was used in all experiments except if otherwise indicated. We used GT1.7, a gonadotropin-releasing hormone secreting tumour cell line with a strong neuronal phenotype [20], a gift from Dr R. Weiner, University of California San Francisco, for the characterisation of glima 38 in cells of neuronal origin. The preparation of radiolabelled detergent phase purified membrane proteins was done as described previously [4] except that the Triton X114 detergent phase [21] of the particulate fraction (PFDP) was subjected to an additional ultracentrifugation at $100000 \mathrm{~g}$ to remove aggregates. The PFDP was precleared twice with normal human serum (NHS) before immunoprecipitation. 
Analyses of antibodies to glima 38, GAD65 and IA-2. Aliquots of Triton X-114 detergent phase extracts (approximately $20 \mu \mathrm{l}$ per immunoprecipitate) containing $4-5 \times 10^{6} \mathrm{cpm}$ were precleared and ultracentrifuged as described above and incubated overnight at $4{ }^{\circ} \mathrm{C}$ with $12 \mu \mathrm{l}$ test serum. Glima 38 antibody-positive and antibody-negative control sera were included in each experiment. Immunocomplexes were isolated using protein A Sepharose (PAS, human sera) or protein G Sepharose (rat sera [22]) (both from Pharmacia LKB Biotechnology, Piscataway, N.J., USA) and washed six times as described previously [4]. The washed PAS pellets were boiled in SDS-sample buffer (60 mmol/1 TRIS-HCl, pH 6.8, $12.5 \%$ glycerol, 80 mmol/1 dithiothreitol, $5 \%$ SDS, $0.01 \%$ bromphenol blue) and analysed by SDS-PAGE using $12 \%$ polyacrylamide gels followed by autoradiography using a PhosphorImager and the Image Quant Version 3.3 software (Molecular Dynamics, Sunnyvale, Calif., USA). Antibodies to GAD65 or IA-2 were analysed using radioligand binding assays $[4,23]$. In each assay, sera were considered positive if the autoantigen was detected in SDS-PAGE analysis of the immunoprecipitate. In the 1995 GAD65 and IA-2 antibody workshop [24], the GAD65 antibody assay had a sensitivity of $88 \%$ in Type I diabetic patients and a specificity of $98 \%$. The IA-2 antibody assay had a sensitivity of $79 \%$ in Type I diabetic patients and a specificity of $97 \%$.

\section{Generation of deglycated glima 38}

Immunoprecipitates of glima 38 were prepared as described above and subjected to enzymatic deglycation according to the manufacturer's instructions. In each case enzymatic reactions were terminated by adding $1 / 3$ volume of $4 \times$ SDS-sample buffer and boiling. Samples were analysed by SDS-PAGE using $15 \%$ polyacrylamide gels followed by autoradiography.

PNGase F. (New England Biolabs, Beverly, Mass., USA). Immunocomplexes isolated on PAS were eluted by boiling for

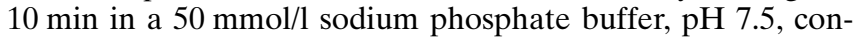
taining $0.05 \%$ SDS and $1 \% \beta$-mercaptoethanol. The PAS was removed by centrifugation and Nonidet P-40 (NP-40, from Calbiochem-Novabiochem, San Diego, Calif., USA) was added to a final concentration of $1 \%$ before incubation with or without 5,000-10 $000 \mathrm{U}$ PNGase F in a final volume of $30 \mu \mathrm{l}$ for $18 \mathrm{~h}$ at either $37^{\circ} \mathrm{C}$ or $4^{\circ} \mathrm{C}$.

Neuraminidase. (Boehringer Mannheim, Indianapolis, Ind., USA). Immunocomplexes were eluted by boiling for $10 \mathrm{~min}$ in a $50 \mathrm{mmol} / \mathrm{l}$ sodium acetate buffer, $\mathrm{pH} 5.0$, containing $0.2 \%$ SDS and $1 \% \beta$-mercaptoethanol. After removal of PAS, supernatants were incubated with $10-50 \mathrm{mU}$ neuraminidase in a final volume of $30 \mu \mathrm{l}$ for $18 \mathrm{~h}$ at $37^{\circ} \mathrm{C}$.

O-Glycosidase. (Boehringer Mannheim). Immunocomplexes were eluted by boiling for $10 \mathrm{~min}$ in $50 \mathrm{mmol} / \mathrm{l}$ sodium phosphate buffer, $\mathrm{pH} 7.5$, containing $0.1 \%$ SDS and $0.7 \% \beta$-mercaptoethanol. After removal of PAS, Triton X-100 was added to a final concentration of $1 \%$ and the supernatants were incubated with $0.5-2.5 \mathrm{mU} \mathrm{O}$-glycosidase in a final volume of $30 \mu \mathrm{l}$ for $18 \mathrm{~h}$ at $37^{\circ} \mathrm{C}$.

To inhibit $N$-glycation of glima 38 in vivo, tunicamycin (5-10 $\mu \mathrm{g} / \mathrm{ml}$ ) (Sigma Chemical Company, St. Louis, Mo., USA) was added to the medium during radiolabelling [26]. Glima 38 was isolated by immunoprecipitation and analysed by SDS-PAGE using $15 \%$ polyacrylamide gels.

In vivo pulse-chase labelling. The synthesis and processing of glima 38 was analysed by pulse-chase-labelling. First $\beta$ TC3- cells were incubated in DME-H21 methionine-free medium containing $1 \%$ dialysed fetal calf serum (Gibco, Rockville, Md., USA) for $40 \mathrm{~min}$ and then with $\left[{ }^{35} \mathrm{~S}\right]$-methionine $(7.4$ $\mathrm{MBq}$ ) for $20 \mathrm{~min}$ followed by immediate replacement of the "pulse" medium with medium containing $0.2 \mathrm{mmol} / \mathrm{l}$ cold methionine ("chase" medium). Plates were harvested at different time points $(0,15,30 \mathrm{~min}$ and 1, 2, 4, $6 \mathrm{~h})$ and processed as described above. The PFDPs were prepared from each time point, immunoprecipitated with glima 38 antibody positive and negative sera and analysed by SDS-PAGE and fluorography.

Western blot analysis of glima 38. Immunoprecipitates of glima 38 were subjected to SDS-PAGE and blotted to a polyvinylidene diflouride (PVDF) membrane. The blots were blocked overnight in $10 \%$ non-fat dry milk in TRIS buffered saline (TBS) containing $0.1 \%$ Tween (TBST) and then incubated with glima 38 antibody positive sera (dilutions: 1:1-1:25 in TBST containing $5 \%$ non-fat dry milk) for $1 \mathrm{~h}$ at room temperature. The blots were washed three times in TBST. Binding of antibodies was made visible using alkaline phosphatase or horseradish peroxidase conjugated anti-human $\mathrm{IgG}$, and chemiluminescence (ECL reagent; Amersham, Arlington Heights, Ill., USA).

\section{Peptide mapping of glima 38 by endoproteinase treatments}

Immunoprecipitates of glima 38 and IA-2 were eluted from PAS and subjected to deglycation with PNGase F. Immunoprecipitates of IA-2 radiolabelled in vitro were processed in parallel to identify IA-2-derived peptides. Enzymatic reactions were terminated by addition of $1 / 3$ volume of $4 \times$ SDS-sample buffer and boiling. Peptides generated by enzymatic cleavage were separated on a $16 \%$ TRIS/Tricine gel [26] and subjected to autoradiography.

Lys-C. (cleavage site: -Lys- $\downarrow-X-$; Boehringer Mannheim). One volume of $200 \mathrm{mmol} / \mathrm{l}$ ammonium bicarbonate buffer, $\mathrm{pH} 8.4$, was added to the sample treated with PNGase F and incubation was continued with or without Lys-C $(0.15-0.3 \mathrm{U}$ in a final volume of $50 \mu \mathrm{l}$ ) for $8 \mathrm{~h}$ at $37^{\circ} \mathrm{C}$.

Asp-N. (cleavage site: - $\downarrow$-Asp/Cys $\mathrm{SO}_{3} \mathrm{H}-\mathrm{X}$ - ; Boehringer Mannheim). One volume of $50 \mathrm{mmol} / \mathrm{l}$ sodium phosphate buffer, $\mathrm{pH} 8.0$ was added to the sample treated with PNGase F and incubation with or without Asp-N (0.04-0.08 $\mu \mathrm{g}$ in a final volume of $50 \mu \mathrm{l}$ ) was continued for $3 \mathrm{~h}$ or $18 \mathrm{~h}$ at $37^{\circ} \mathrm{C}$.

Glu-C/V8. (cleavage site: -Glu- $\downarrow-\mathrm{X}-$; Boehringer Mannheim). One volume of $50 \mathrm{mmol} / \mathrm{l}$ ammonium bicarbonate buffer $\mathrm{pH}$ 7.8 was added to the sample treated with PNGase F and incubation with or without Glu-C/V8 (1-2 $\mu \mathrm{g}$ in a final volume of $50 \mu \mathrm{l})$ was continued for $3 \mathrm{~h}$ or $18 \mathrm{~h}$ at $25^{\circ} \mathrm{C}$.

Lectin affinity chromatography of glima 38. The following lectins were obtained from EY Laboratories, San Mateo, Calif., USA), and tested for their ability to bind the glycated form of glima 38: Canavalia ensiformis (ConA), Lens culinaris (LcH), Ricinus communis I (RCA-I), Triticum vulgare (WGA), Arachis hypogaea (PNA), Ulex europaeus I (UEA), Lycopersicon esculentum (LEA) and Maackia amurensis (MAA). Immobilised lectin columns $(500 \mu \mathrm{l})$ were equilibrated with 10 gel volumes of $10 \mathrm{mmol} / \mathrm{l}$ phosphate buffered saline (PBS), $\mathrm{pH} 7.45$ (RCA-I, WGA, UEA-I, PNA, LEA, and MAA) or $50 \mathrm{mmol} / \mathrm{l}$ 
TBS, pH 7.0-7.2 (ConA and $\mathrm{LcH}$ ). Aliquots of precleared PFDP from $\beta$ TC3 cells were applied to the columns and incubated for $15 \mathrm{~min}$. Columns were washed with buffers (see above) to remove unbound material. Bound material was eluted using 2-3 gel volumes of buffer containing the appropriate competing carbohydrate according to the manufacturers instructions. After elution, the columns were washed with 10 gel volumes of $1.0-1.4 \mathrm{~mol} / \mathrm{l} \mathrm{NaCl}$ in distilled water and re-equilibrated by washing with about 50 gel volumes of storage buffer (PBS or TBS containing $0.1 \%$ sodium azide). Flow-through, wash fractions and eluted fractions were immunoprecipitated with a glima 38 antibody positive serum and analysed by SDSPAGE and autoradiography.

Immunoaffinity chromatography of glima 38. Purified $\mathrm{IgG}$ from plasma of the glima 38 antibody-positive Type I diabetic patient (U80) was coupled to protein A Sepharose beads to generate an affinity matrix for the purification of glima 38. Immunoglobulin $\mathrm{G}$ was incubated with preswollen PAS $(6 \mathrm{mg} \mathrm{IgG}$ per $\mathrm{ml}$ swollen gel) in PBS at $4{ }^{\circ} \mathrm{C}$ for $1 \mathrm{~h}$ on a rotor. The beads were washed twice with 10 bead volumes of $200 \mathrm{mmol} / 1 \mathrm{Na}^{+}$-borate $\mathrm{pH}$ 9.0. Cross-linking was done by incubation in $20 \mathrm{mmol} / \mathrm{l}$ dimethylpimelimidate for $30 \mathrm{~min}$ at $25^{\circ} \mathrm{C}$ on a rotor. The reaction was stopped by adding 10 bead volumes of $200 \mathrm{mmol} / \mathrm{l}$ ethanolamine, $\mathrm{pH} 8.0$ and mixing gently for $2 \mathrm{~h}$ at $25^{\circ} \mathrm{C}$. The effectiveness of coupling was analysed by SDS-PAGE using aliquots before and after the addition of dimethylpimelimidate. Beads used for immunoaffinity chromatography had a coupling effectiveness of $95 \%$ or more. Before immunoaffinity chromatography, the beads were prewashed sequentially with the following solutions: $100 \mathrm{mmol} / \mathrm{l} \mathrm{NaHCO}_{3}, \quad \mathrm{pH} \quad 8.0 ; 1 \mathrm{~mol} / \mathrm{l} \mathrm{NaCl}$; $100 \mathrm{mmol} / \mathrm{l}$ acetic acid, $\mathrm{pH} 4.0$; and $1 \mathrm{~mol} / \mathrm{l} \mathrm{NaCl}$. Finally the beads were washed and resuspended in $10 \mathrm{mmol} / 1 \mathrm{HEPES}, \mathrm{pH}$ 7.4, containing $150 \mathrm{mmol} / \mathrm{l} \mathrm{NaCl}, 10 \mathrm{mmol} / \mathrm{l}$ benzamidine, $5 \mathrm{mmol} / \mathrm{l}$ EDTA, $100 \mathrm{mg} / \mathrm{l}$ BSA, $1 \%$ Triton X-114.

Aliquots of radio labelled PFDP from $\beta$ TC3 cells were precleared by a batchwise incubation with beads prepared as described above but using IgG from normal human serum. The precleared extract was incubated at $4{ }^{\circ} \mathrm{C}$ for with $\mathrm{U} 80 \mathrm{IgG}$ immunoaffinity beads $\left(170 \times 10^{6} \mathrm{cpm} / \mathrm{ml}\right.$ packed beads $)$ by gentle rotation. Maximum binding of glima 38 to the immunoaffinity resin was achieved after a 1 -h incubation (as determined in pilot experiments). The beads were then poured on a column. The flow-through was collected, followed by ten washes (2bead volumes each) before elution of bound material. After optimising of the elution conditions (data not shown), bound proteins were eluted with $100 \mathrm{mmol} / \mathrm{l}$ glycine $\mathrm{pH} 3.0$ (0.5-bead volumes each) and neutralised with $1 / 10$ volume of $1 \mathrm{~mol} / 1$ TRIS-HCl pH 8.0. Columns were regenerated and stored in PBS/0.01\% Thiomersal (Sigma, St. Loius, Minn., USA). Aliquots of the total extract loaded (1/20) and the flow-through $(1 / 20)$, as well as the wash fractions and the eluted fractions were divided into two fractions for further analysis. The first fraction was immunoprecipitated with glima-38, antibody-positive serum to identify fractions containing glima 38 . The second fraction was subjected to precipitation with $10 \%$ trichloric acid, followed by an acetone wash, to analyse the protein content of the respective fractions. Precipitates were analysed by SDS-PAGE and phosphorimaging.

\section{Results}

Identification of high-titre, glima-38 antibody-positive sera. Newly diagnosed patients with Type I diabetes $(n=44)$ were analysed for glima 38 antibodies to identify high-titre, antibody-positive sera for biochemical studies. Amongst those, ten $(22.7 \%)$ were glima-38, antibody-positive (Table 1). In the cohort of 44 patients, the prevalence of GAD65 autoantibodies (GADA) was $79.5 \%$ and of antibodies to IA2 (IA-2A) $84.1 \%$ (data not shown). Glima-38, antibody-positive patients were younger than antibody-negative patients (mean age $\pm \mathrm{SD}$; median: $14.1 \pm 13.1$; 10 years; vs $24.2 \pm 14.5$; 22 years; Wilcoxon rank test: $p=0.049$ ). Patients below the age of 17 years (median of study group), were twice as frequently positive for glima 38 antibodies than patients older than 17 years $(28.6 \%$ and $13.6 \%)$. Of the ten glima-38, antibody-positive patients, eight were positive for GADA and all ten for IA-2A (Table 1). Glima 38 antibodies were also found before clinical onset of diabetes in two ICA-positive and IAA-positive but GADA-negative and IA-2A-negative, first-degree relatives (Table 1, No. 11 and 12). One of the two glima-38, antibody-positive relatives (U122) developed Type I diabetes 2 years after the serum was collected. Glima 38 antibodies disappeared within 6 months after clinical diagnosis of Type I diabetes in one of the four subjects from whom consecutive serum samples were available (U38). The other three remained glima-38, antibody-positive over a period of 2 weeks - 0.6 years (U9, U47, U76). Sera from patients 5,9 and 11 and plasma from patient 9 (Table 1), who were strongly positive for glima 38 autoantibodies, were used for biochemical analysis in this study.

Glima 38 is not recognised by BB-rat sera. Glima 38 antibodies have only been described in human Type I diabetes [4]. One group [14, 16] reported that sera from $B B$-rats immunoprecipitate a $38000 \mathrm{M}_{\mathrm{r}}$ protein in membrane extracts of isolated islet cells from $B B$ rats. This $38000 \mathrm{M}_{\mathrm{r}}$ antigen is a well-defined narrow band on SDS-gels, suggesting that it is not glycated $[14,16]$. We tested five $B B$-rat sera that were antibody positive and five that were antibody negative to $38000 \mathrm{M}_{\mathrm{r}}$ antigens for reactivity with glima 38 in parallel with two glima-38, antibody-positive and two negative control sera. None of the $B B$-rat sera recognised glima 38 (results not shown). Thus, it appears that glima 38 is distinct from the protein described previously $[14,16]$.

The $N$-glycan of glima 38 contains terminal sialic acids and inhibition of glycation shows a core protein of $M_{r}$ 22000 . Enzymatic deglycation of glima 38 in vitro, using PNGase F results in a protein of $\mathrm{M}_{\mathrm{r}} 22000$ [4]. To find whether PNGase F removes all $N$-linked carbohydrates in the protein, tunicamycin, which blocks $N$-glycation in vivo, was included in biosynthetic labelling experiments of glima 38 . In the presence of tunicamycin, glima 38 is synthesised as a protein of $\mathrm{M}_{\mathrm{r}}$ 22000 (Fig.1A), consistent with results using PNG- 
A

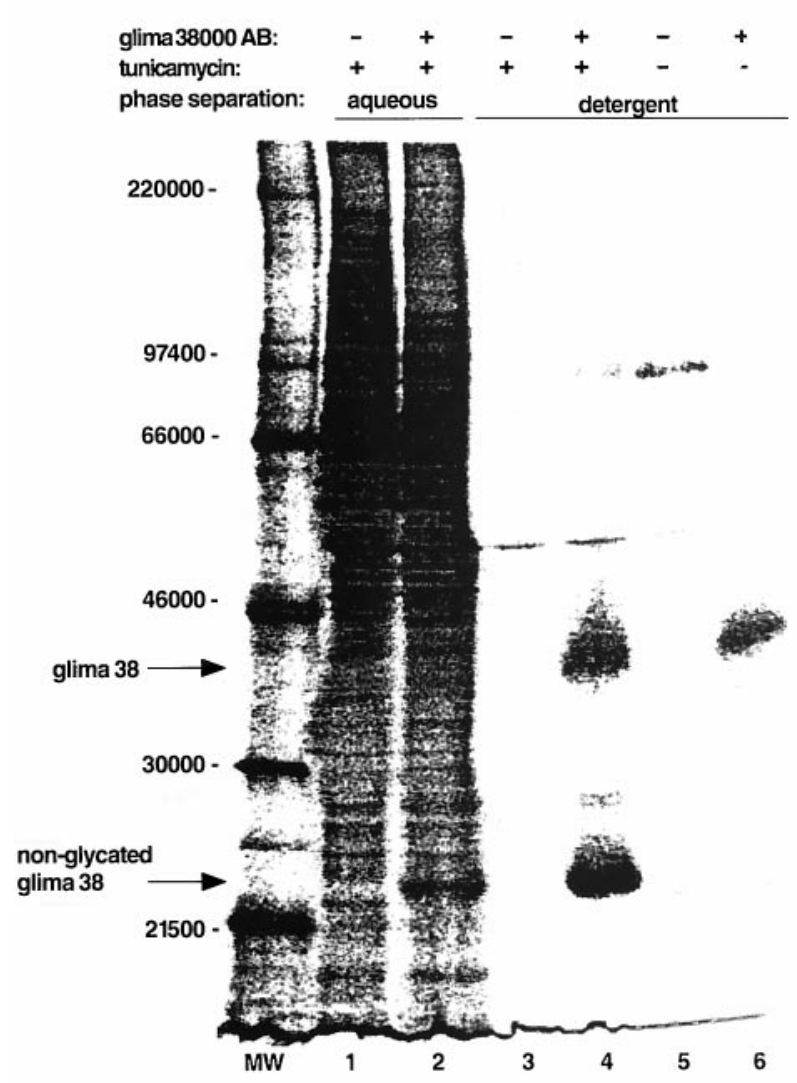

Fig.1A, B. Characterisation of the glycation of glima 38. SDSPAGE analysis of immunoprecipitates of non-glycated and deglycated glima 38. A Inhibition of $N$-glycation of glima 38 in vivo. Immunoprecipitates of aqueous or detergent phase extracts of $\beta$ TC3 cells radiolabelled in the presence (lanes 1-4) or absence (lanes 5-6) of tunicamycin. Immunoprecipitation was carried out using normal human serum (lanes 1, 3, and 5) or a glima 38 antibody positive serum (lanes 2,4 , and 6 ). Inhibition of $N$-glycation in vivo shows a $\mathrm{M}_{\mathrm{r}} 22000$ amphiphilic core protein of glima 38. B Enzymatic deglycation of glima 38 in vitro. Autoradiography by phosphorimaging of an SDSPAGE analysis of immunoprecipitates of detergent phase extracts of $\beta$ TC3 cells radiolabelled in the presence or absence of tunicamycin. Samples were subjected to incubations with PNGase F (A, lane 6), neuraminidase (B, lane 7), $O$-glycosidase $(\mathrm{C}$, lane 8$)$ or IP buffer (lane 5 ) at $37^{\circ} \mathrm{C}$ for $18 \mathrm{~h}$. Immunoprecipitation was with normal human serum (lanes 1 and 3 ) or a glima 38 antibody-positive serum (lanes 2 and 4-8). Mature glima 38 contains terminal sialic acids, whereas the $M_{r} 22000$ form appears to represent the non-glycated core protein of glima 38

ase. Pulse-chase experiments showed that glima 38 is fully glycated in vivo within $1 \mathrm{~h}$ (results not shown). To further evaluate whether the $\mathrm{M}_{\mathrm{r}} 22000$ component derived from glima 38 is fully deglycated, immunoprecipitates of the $M_{r} 22000$ protein (obtained by tunicamycin treatment) were incubated with PNGase $\mathrm{F}$, neuraminidase, or $O$-glycosidase, respectively. None of these enzymes mediated a shift of the mobil-
B

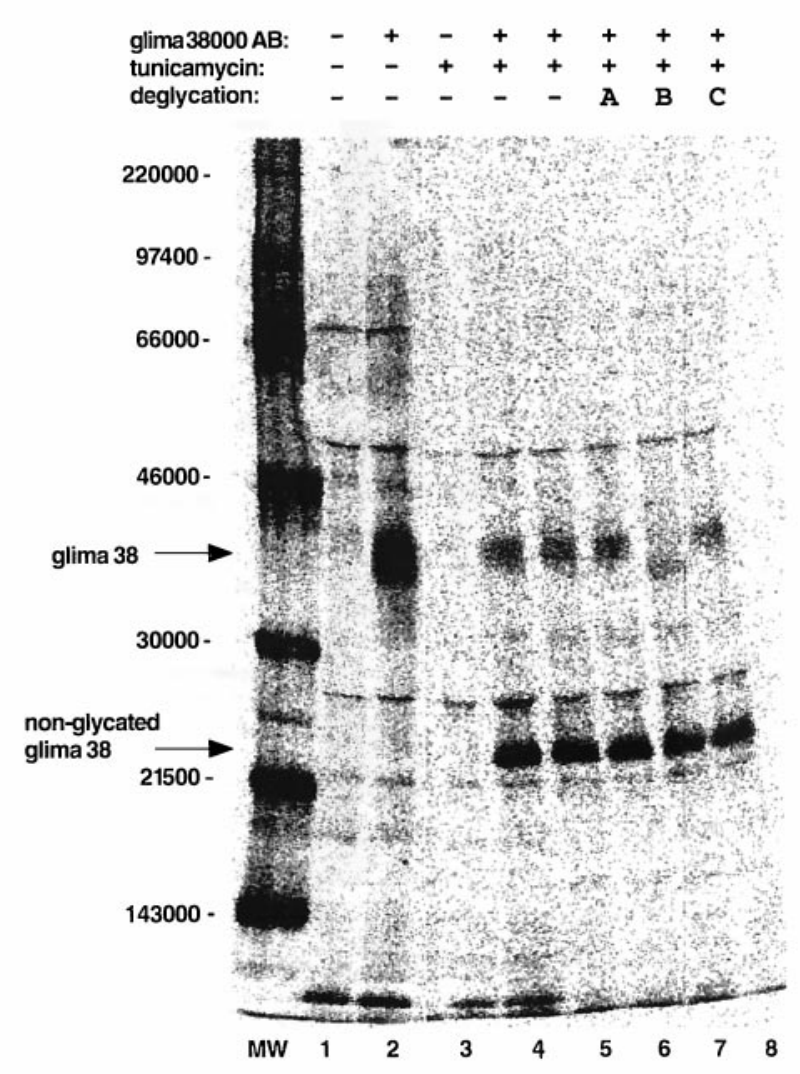

ity of the $M_{r} 22000$ protein on SDS-gels (Fig.1B), suggesting that the $M_{r} 22000$ protein is the non-glycated core of glima 38 . Neuraminidase treatment resulted, however, in a shift of the mobility of the glycated form of glima 38, indicating the presence of terminal sialic acids in the carbohydrate moiety (Fig.1B, lane 7). The $O$-glycosidase did not affect the mobility of either the $M_{r} 38000$ or $M_{r} 22000$ forms of glima 38 on SDS-PAGE (Fig.1B, lane 8), suggesting that the protein does not contain $O$-linked carbohydrate moieties. In the absence of a positive control, the evidence is, however, only suggestive. In conclusion, more than about $40 \%$ of the relative molecular weight of glima 38 is contributed by carbohydrates. Since one oligosaccharide chain of glycoproteins equals on average $M_{r} 300-3000$, glima 38 is likely to contain a minimum of five carbohydrate chains and is thus heavily glycated.

Evidence for different glycation patterns of glima 38 in pancreatic beta cells and neuronal cells. Glima 38 is expressed in pancreatic as well as in neuronal cell lines [4]. Immunoprecipitation and SDS-PAGE analysis of glima 38 from $\beta$ TC3 (pancreatic) and GT1.7 (neuronal) cell lines shows that the neuronal protein has a lower mobility than the beta-cell protein on SDS-gels (Fig. 2A; lanes 3,4). Tunicamycin treatment during radiolabelling in vivo results, however, in a core protein of identical mobility from both cell types 


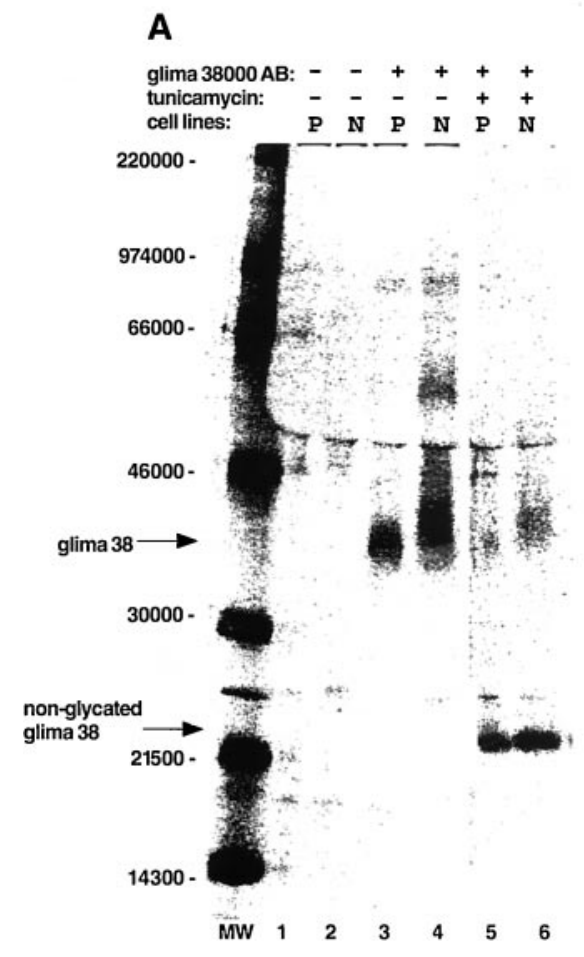

Fig. 2A, B. Analysis of glima 38 in islet and neuronal cell lines. SDS-PAGE analyses of immunoprecipitates of detergentphase extracts from either pancreatic $\beta$ TC3 cells $(\mathrm{P})$ or neuronal GT1.7 cells (N) A Islet cell and neuronal glima 38 share a similar protein core but differ in $N$-linked carbohydrate moieties. Cells were radiolabelled in the presence or absence of tunicamycin and immunoprecipitation was done using normal human serum (lanes 1 and 2) or a glima 38 antibody positive serum (lanes 3-6). The mobility of mature, glycated glima 38 in neuronal and beta cell lines differs, whereas the non-glycated core protein has a $\mathrm{M}_{\mathrm{r}}$ of 22000 in both cell types. B Sialylation of glima 38 in islet and neuronal cell lines. Cells were incubated with or without neuroaminidase. Glima 38 in both cell types contains terminal sialic acids, but this modification does not seem to account for the differences in mobility on SDSPAGE

(Fig.2A; lanes 5,6). These results suggest that the core protein is identical but that the glycation patterns differ in the two cell types. The distinct mobilities do not seem to result from differences in sialylation because a neuraminidase treatment of glycated glima 38 results in a similar shift in mobility on SDSpolyacrylamide gels (Fig.2B). Rather, the earlier steps in glycation of glima 38 could differ between beta cells and neurons.

B-cell epitopes in glima 38 are dependent on conformation but do not require the oligosaccharide moiety. Autoantibodies to glima 38 in sera from Type I diabetic patients recognise the glycated and non-glycated forms of glima 38 equally well (Fig.1), suggesting that the carbohydrate moiety is not a part of the autoreactive B-cell epitopes. To assess whether the auto-

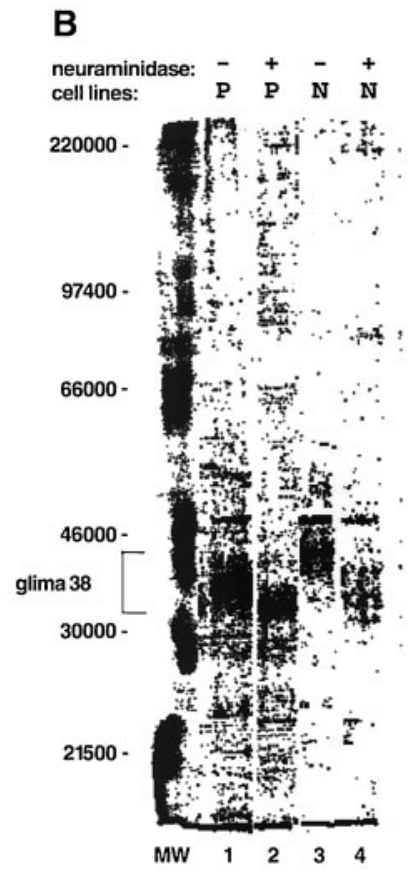

reactive epitopes in glima 38 are dependent on conformation, the five sera of highest immunoreactivity identified in this study were incubated with denatured glima 38 on western blots. Immunoprecipitates of glima 38 were subjected to denaturing SDSPAGE followed by blotting of protein to PVDF membrane and probing with sera at serial dilutions. None of the sera recognised glima 38 on western blots suggesting that as for GAD65 and IA-2, the autoimmune epitopes are conformational rather than linear (data not shown).

Endoprotease treatment of glima 38 using Lys-C, Asp$N$ and $G l u-C / V 8$ shows specific peptide fragments. To evaluate potential cleavage sites and generate peptide maps of glima 38, endoproteinase digests were done on the protein isolated by immunoprecipitation and eluted from protein A Sepharose. Because the serum used for those studies is also weakly positive for IA-2A, IA-2; transcribed and translated in vitro; was immunoprecipitated and processed in parallel to identify peptides potentially derived from IA-2. In preliminary experiments, using a variety of incubation conditions, glycated glima 38 remained intact (data not shown), suggesting that the carbohydrate modification renders the protein resistant to proteolysis (results not shown). When proteinase incubations were carried out using deglycated protein, several specific peptides were, however, generated (Fig.3). Thus, the treatment of immunoprecipitated and deglycated protein with Lys-C resulted in specific peptide fragments of $M_{r} 4500$ and $M_{r} 20000$ (Fig.3A, lanes 3,4$)$. These fragments are likely to be derived from glima 38 and not from low levels of IA-2 present 

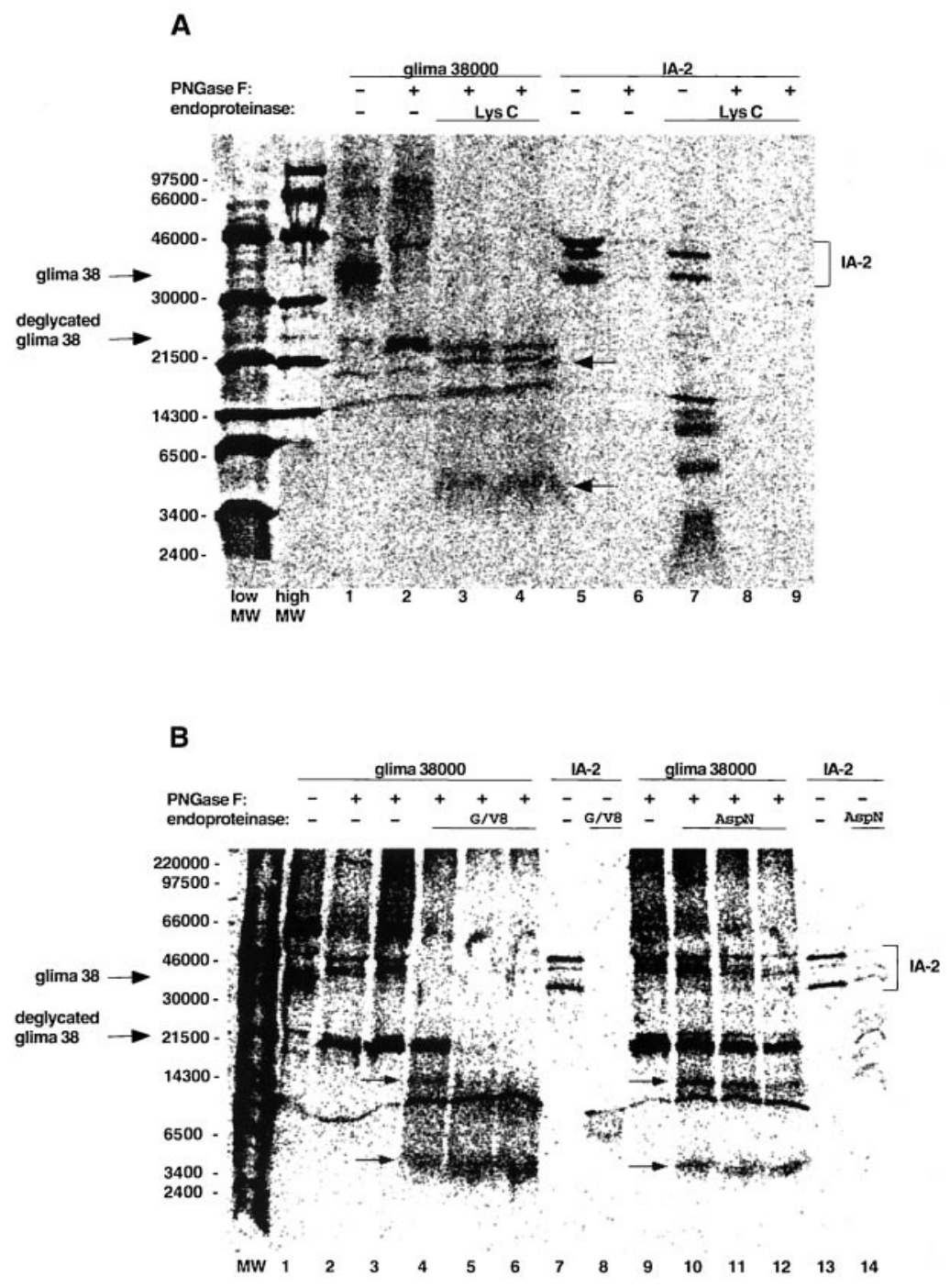

Fig.3 A, B. Peptide mapping of glima 38. SDS-PAGE analyses of glima 38 immunoprecipitated from $\beta$ TC3 cells (serum U76) and incubated with endoproteinases. A Lys-C digestion. Immunoprecipitates were incubated with buffer (lane 1), PNGase F (lane 2) or PNGase F followed by treatment with $0.15 \mathrm{U}$ (lane 3 ) or $0.3 \mathrm{U}$ of Lys-C (lane 4). IA-2 generated by in vitro transcription/translation was immunoprecipitated in parallel with the same serum and incubated similarly with buffer (lane 5), PNGase F (lane 6), or PNGase F followed by $0.15 \mathrm{U}$ (lane 8 ) or 0.3 U Lys-C (lane 9). Lys-C digestion of deglycated glima 38 results in the appearance of two specific bands at $M_{r} 4500$ and 20000 respectively (indicated by arrows), which are not detected in Lys-C digests of IA-2. B Glu-C/V8 and Asp-N digestion. Immunoprecipitates were treated with buffer (lane 1), PNGase F (lanes 2 and 9) or PNGase F followed by incubation with Glu-C/V8 (lanes 4-6) or Asp-N (lanes 10-12). In vitro transcribed/translated IA-2 was immunoprecipitated with the same serum and incubated (with or without a prior deglycation treatment) in parallel. Fragments that seem to be specifically derived from glima 38 are marked with an arrow. Glu-C/ V8 digestion results in fragments of $\mathrm{M}_{\mathrm{r}} 4000$ and 12000 respectively, which are not detected in IA-2 digests. Asp-N digestion similarly results in two fragments of $M_{r} 4000$ and 11000 respectively, which are not detected in digests of IA-2. Amount of enzyme per $50 \mu \mathrm{l}$ : Lanes 4, 5, 8: $1 \mu \mathrm{g}$; lane 6: $2 \mu \mathrm{g}$; lanes 10,11, and 14: $0.04 \mu \mathrm{g}$; lane 12: $0.08 \mu \mathrm{g}$. Incubation time for lanes 3 and 4. $3 \mathrm{~h}$ and lanes 5, 6, 8, 11, 12, and 14, $18 \mathrm{~h}$ in the immunoprecipitates for the following reasons: Firstly, IA-2; transcribed/translated in vitro and immunoprecipitated with U77, was completely degraded when subjected to a PNGase F treatment followed by incubation with either Lys-C (Fig. 3A, lanes 8,9) or buffer (Fig.3A, lane 6). Thus in contrast to glima 38, deglycated IA-2 is completely degraded in the conditions used here. Secondly, the peptide fragments generated by Lys-C treatment of glycated IA-2 with Lys$\mathrm{C}$ resulted in peptide fragments which were distinct from the $M_{r} 4400$ and $M_{r} 20000$ fragments generated from the preparation containing glima 38 (Fig.3A, lane 7). Similarly, digestion of glima 38 and IA-2 using either Glu-C/V8 or Asp-N (Fig.3B) showed in both cases the appearance of peptides specific for glima 38 of approximately $M_{r} 4500$ and $M_{r} 11000$ 12000 (Fig. 3B, lanes 4-6, 10-12). These bands were not detected after digestion of IA-2 (Fig.3B, lanes $8,14)$. Thus, each of the three proteinases generates specific glima 38 peptides. 


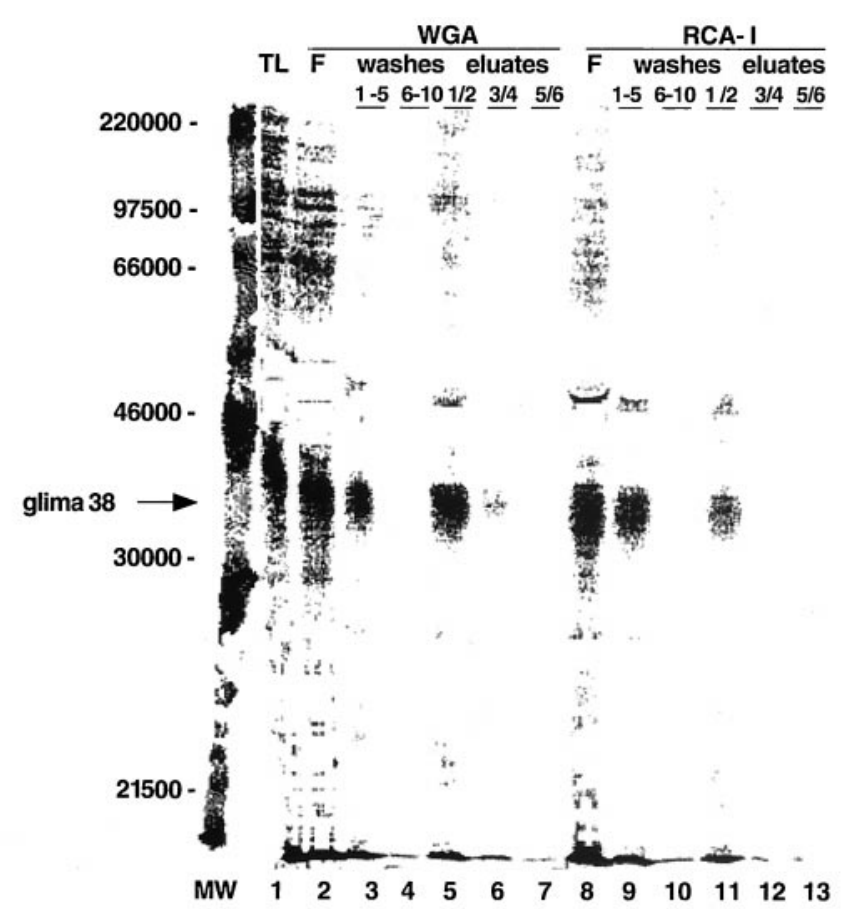

Fig.4. Lectin affinity chromatography of glima 38. Phosphorimaging of SDS-PAGE analysis of immunoprecipitates of glima 38 from fractions obtained by affinity chromatography on colums of WGA (lanes 1-7) and RCA-1 (lanes 8-13). Lane 1 shows glima 38 in the sample applied to the columns. Glima 38 is detected in the flow through (lanes 2 and 8) and wash fractions (lanes $3,4,9$, and 10) as well as in fractions specifically eluted from the columns (lanes 5-7 and 11-13).

Lectin binding of glima 38 shows a complex glycoprotein character. The glycated form of glima 38 binds to both castor bean lectin (RCA-I) and wheat germ agglutinin (WGA; Fig. 4A) but not to the six other lectins of different specificities tested in this study. The castor bean lectin is specific for lactose and galactose, and furthermore, binds to branched cluster oligosaccharides. Wheat germ agglutinin is specific for oligomers of $(1,4)$-linked $N$-acetyl-glucosamine but also reacts with terminal sialic acid residues. Although glima 38 was specifically eluted from these lectin columns using the appropriate competing carbohydrates, a fraction of glima 38 was detected in the flow-through and in the first washes, suggesting a possible heterogeneity of the carbohydrate moieties (Fig. 4A). Affinity to WGA is a characteristic of biantennary complex-type glycoproteins ( $N$-linked), which also bind to RCA-I. Mucin-type glycoproteins $(O$-linked) also bind to WGA, but do not bind to RCA-I $[27,28]$. Binding to lectins like ConA or $\mathrm{LcH}$ is a characteristic of triantennary complex-type and high mannose-type glycoproteins [27, 28]. The binding of glima 38 to WGA and RCA-I, the absence of $O$-linked carbohydrates and the lack of binding to $\mathrm{LcH}$ and ConA is consistent with the presence of biantennary complex-type carbohydrates in this protein.
Immunoaffinity chromatography using human polyclonal autoantibodies yields low levels of relatively pure glima 38. Different approaches were taken in attempts to purify glima 38. An immunoprecipitate of glima 38 is relatively free of contaminating ${ }^{35} \mathrm{~S}$ methionine-labelled, $\beta$ TC-3-cell proteins but contains several fold excess of cold IgG. Attempts to efficiently separate IgG from glima 38 by preparative SDSPAGE were unsuccessful. We therefore immobilised IgG, purified from plasma containing glima 38 autoantibodies, on PAS to generate an immunoaffinity column. Binding and elution conditions for immunoaffinity chromatography of glima 38 were determined empirically using different buffer systems. Under alkaline conditions, elution of glima 38 was only achieved at very high $\mathrm{pH}(\geq 11.3)$ which was not compatible with reuse of columns. Mild acidic elution conditions enabled, however, reuse of columns and resulted in a moderate recovery of protein. Most contaminating proteins were collected in the flowthrough (Fig.5) or removed during washes from the immunoaffinity resins. Glima 38 was the predominant protein $(\sim 40 \%$ of total protein) eluted under acidic conditions (Fig. 5). In contrast, glima 38 is not discernible in SDS-PAGE analyses of total lysates of $\beta$ TC3 cells (results not shown). Thus, the immunoaffinity chromatography resulted in a major degree of purification of glima 38. In all experiments regardless of the conditions, the yield of glima 38 eluted from immunoaffinity columns (per $\mathrm{mg}$ IgG bound to resin) was, however, very low and only a small fraction of the yield from immunoprecipitates using similar quantities of IgG (Fig. 5) suggesting a low capacity of the coupled anti-glima $38 \mathrm{IgG}$. This is likely to reflect the inherent problem of using a polyclonal $\mathrm{IgG}$ for immunoaffinity chromatography compounded with the relatively low titre of diabetic autoantibodies. Furthermore, the coupling reaction could result in some loss of affinity. The low yield in the present experiments is consistent with results using GAD65 specific human autoantibodies for immunoaffinity resins (S. Baekkeskov unpublished results). The binding efficiency of the immunoaffinity resin was not enhanced using deglycated glima 38 (data not shown). Thus, although immunoaffinity using polyclonal human autoantibodies results in a high degree of purification of glima 38 , it is unlikely to present an optimal method for purifying the protein.

\section{Discussion}

A prevalence of $19 \%$ and $14 \%$ was previously reported for antibodies to glima 38 in 86 newly diagnosed Type I diabetic patients and 44 prediabetic subjects, respectively [4]. This study found a similar prevalence $(22.7 \%)$ in 44 new-onset patients. Thus, approximately every fifth patient has an ongoing im- 
A

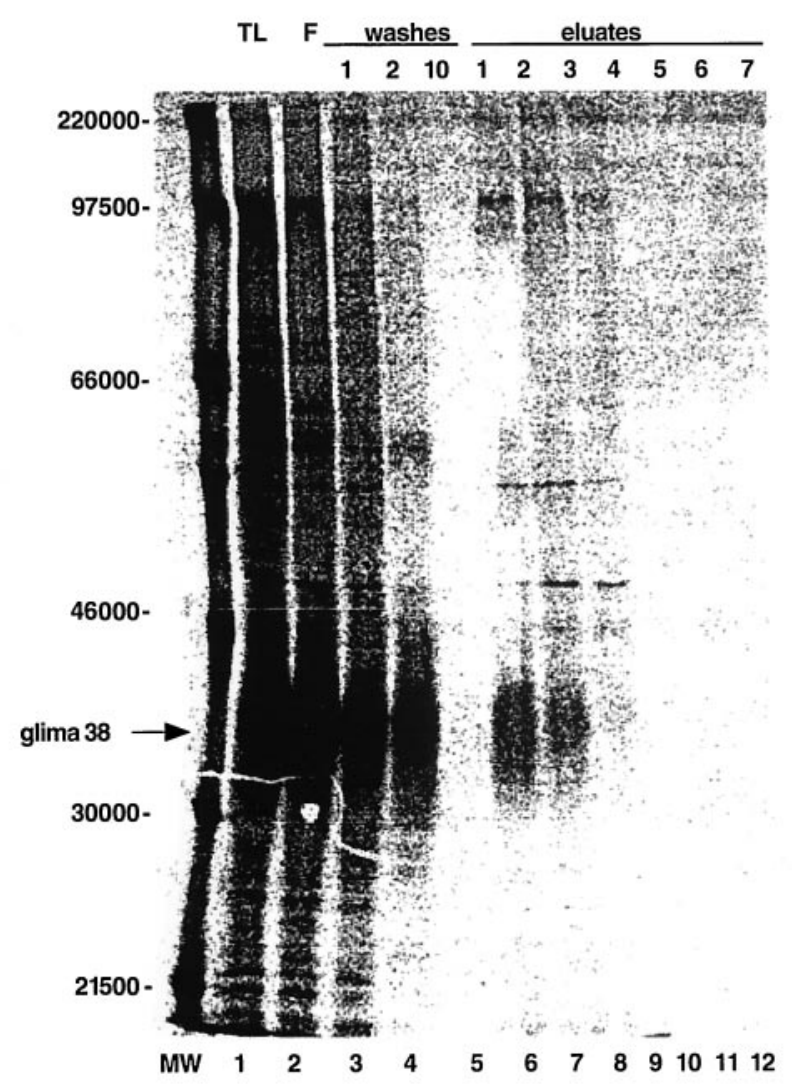

B

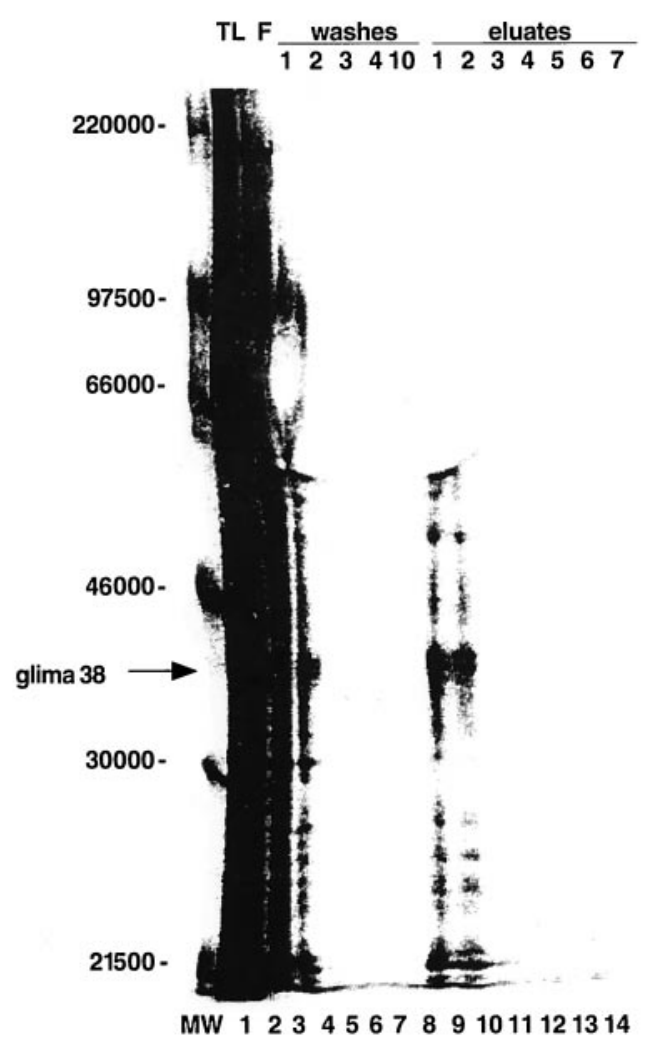

Fig.5A, B. Immunoaffinity chromatography of glima 38 . SDS-PAGE analyses of immunoprecipitates (A) and TCA precipitates (B) of fractions obtained by immunoaffinity chromatography of a detergent phase extract of $\beta$ TC3 membrane proteins using $\mathrm{IgG}$ purified from plasma of a glima 38 antibody positive patient. Immunoaffinity beads $(0.6 \mathrm{ml}$, containing $3.4 \mathrm{mg}$ bound $\mathrm{IgG}$ ) were incubated batchwise with precleared lysate $\left(100 \times 10^{6} \mathrm{cpm}\right)$ and poured on a column. A Analysis of glima 38 in different fractions by immunoprecipitation. An aliquot $\left(1 / 20,5 \times 10^{6} \mathrm{cpm}\right)$ of total lysate loaded (TL), 1/20 of the flow through $(\mathrm{F})$, and $1 / 2$ of the wash fractions and eluted fractions were immunoprecipitated with the U77 serum $(250 \mu \mathrm{g}$ $\mathrm{IgG}, 25 \mu \mathrm{l}$ PAS). Because the column was overloaded to ensure maximum binding, a large fraction of glima 38 appears in the flow through (lane 2) and wash fractions (lanes 3 and 4). A small amount of glima 38 is bound to and specifically eluted from the column (lanes 6 and 7). B Analysis of total protein in different fractions. A duplicate of the fractions used in $\mathbf{A}$ was precipitated with TCA. Glima 38 is the major protein ( $\sim 40 \%$ of total protein) eluted in the first two fractions from the immunoaffinity column (lanes 8 and 9)

mune response to this autoantigen. In a previous study glima 38 antibodies were detected in 6 out of 44 prediabetic children up to several years before a clinical onset of Type I diabetes. Furthermore antibodies to glima 38 were detected in one of five subjects identified as ICA, GADA, and/or IA-2A positive in a general population screening of 1403 schoolchildren. The child who was positive for glima 38 an- tibodies developed Type I diabetes during follow-up [29]. The seven prediabetic children who were positive for glima 38 antibodies in the earlier studies were also positive for either GADA, IA-2A or both $[4,29]$. The first-degree relative who was positive for glima 38 antibodies in the present study and who developed Type I diabetes during follow-up (2 years later) was, however, GADA and IA-2A negative suggesting that glima 38 autoantibodies can precede both.

Glima 38 is a $N$-linked glycoprotein with a protein core of $\mathrm{M}_{\mathrm{r}} 22000$, based on two distinct analyses: (i) deglycation of mature glima 38 in vitro, using PNGase F, which cleaves $N$-linked carbohydrates at the protein core [25] and (ii) inhibition of $N$-linked glycation in vivo, using tunicamycin which blocks the coupling of $N$-linked glycans to the protein core in the endoplasmic reticulum [25]. The $O$-glycosidase failed to shift the mobility of the $\mathrm{M}_{\mathrm{r}} 22000$ protein on SDSgels suggesting that the protein does not undergo this type of glycation. We therefore conclude that deglycated glima 38 is a molecule of $\mathrm{M}_{\mathrm{r}} 22000$.

Results of analysis of the carbohydrate moieties of glima 38 suggest that it is an $N$-linked glycoprotein of the biantennary complex-type [27, 28]. Notably, antibodies to glima 38 recognise both the glycated and non-glycated form of the protein, indicating that Bcell epitopes are located outside the glycated region. The biological activity of most glycoproteins does 
not change when the carbohydrates are removed. In some cases saccharide moieties seem, however, to have a structural role $[25,28,30]$. For example, in chronic atrophic gastritis, binding of autoantibodies to the $\mathrm{M}_{\mathrm{r}} 60$ 000-90 $000 \beta$-subunit of $\mathrm{H}+/ \mathrm{K}+$ ATPase, which is a heavily glycated $\mathrm{M}_{\mathrm{r}} 35000$ core protein with 6-7 potential $N$-glycation sites and additional $O$-glycans, requires both the specific carbohydrate and the protein moieties of the antigen. Thus, the three-dimensional protein structure is critically dependent on the presence of correctly processed glycans. For glima 38, the tertiary structure of the protein moiety itself seems to be crucial in binding of antibodies, whereas the integrity of the carbohydrate structure is not.

The IA-2 autoantigen in Type I diabetes is also $\mathrm{N}$ glycated. It is synthesised as a $\mathrm{M}_{\mathrm{r}} 105000$ core protein, which undergoes glycation resulting in a mobility corresponding to $M_{r} 120000$ on SDS-gels [6, 8, 31]. The carbohydrate moiety in glima 38 does not, however, seem to contribute to the autoreactive epitopes in the molecule [7]. Thus, glycation of both glima 38 and IA-2 antigens is not an integral part of their autoreactive epitopes.

The different glycation of glima 38 in beta cells and neurons could be due to expression of tissue-specific glycation enzymes in the two cell types [26]. Given that glima 38 contains at least 5 oligosaccharide chains, representing more than $40 \%$ of the final weight of the mature protein, there are many potential sites for variability in oligosaccharide synthesis. For instance, many glycoproteins from the brain contain an abundance of mannose-rich hetero-oligosaccharide chains localised predominantly in synaptosomal, myelin-enriched and microsomal fractions [32].

The peptide and glycation patterns of glima 38 described in this study are important parameters for its unequivocal identification and can, together with its membrane localisation, hydrophobicity and affinity to diabetes-specific antibodies, form the basis for its complete characterisation.

Acknowledgements. We thank Dr M. Hummel (Third Medical Department, City-Hospital Schwabing, Munich) for sera from Type I diabetic patients and Drs R. A. Koll (Therasorb Medizinische Systeme, Munich), H.-C. Geiss, M. G. Donner, M.M. Ritter and P. Schwandt (Medical Department II, Hospital Grosshadern, Munich), for IgG purified from plasma of a patient with Type I diabetes antibody positive for glima 38 .

This work was funded by NIH grants DK 41822 and DK 47043 (S. Baekkeskov), M01 RR 01271 (Pediatric Clinical Research Center, University of California San Francisco), the American Diabetes Association and the Juvenile Diabetes Foundation International (S . Baekkeskov). U. Roll was supported by a postdoctoral fellowship from the German Research Foundation (Ro 1194/1-1).

\section{References}

1. Ziegler AG, Eisenbarth GS (1990) Immunology of diabetes. In: Alberti KGMM, Krall PS (eds) Diabetes Annual 5. Elsevier, Amsterdam, pp 20-50

2. Roll U, Ziegler AG (1997) Combined antibody screening for improved prediction of IDDM - Modern strategies. Exp Clin Endocrinol Diabetes 105: 1-14

3. Baekkeskov S, Aanstoot HJ, Christgau S et al. (1990) Identification of the $64 \mathrm{k}$ autoantigen in insulin-dependent diabetes as the GABA-synthesizing enzyme glutamic acid decarboxylase. Nature 347: 151-156

4. Aanstoot HJ, Kang SM, Kim J et al. (1996) Identification and characterization of Glima 38, a glycosylated islet cell membrane antigen, which together with GAD65 and IA2 marks the early phases of autoimmune response in type 1 diabetes. J Clin Invest 97: 2772-2783

5. Hawa M, Rowe R, Lan MS et al. (1997) Value of antibodies to islet protein tyrosine phophatase-like molecule in predicting type 1 diabetes. Diabetes 48: 1270-1275

6. Rabin DU, Pleasic SM, Shapiro JA et al. (1994) Islet cell antigen 512 is a diabetes-specific islet autoantigen related to protein tyrosine phosphatases. J Immunol 152: 3183-3188

7. Payton M, Hawkes C, Christie MR (1996) Relationship of the 37,000- and 40,000-Mr tryptic fragment of islet antigens in insulin-dependent diabetes to the protein tyrosine phosphatase-like molecule IA-2 (ICA512). J Clin Invest 96: 1506-1511

8. Passini N, Larigan JD, Genovese S, Appella E, Sinigaglia F, Rogge L (1995) The 37/40-kilodalton autoantigen in insulin-dependent diabetes mellitus is the putative tyrosine phosphatase IA-2. Proc Natl Acad Sci USA 92: 9412-9416

9. Lan MS, Wasserfall C, Maclaren NK, Notkins AL (1996) IA-2, a transmembrane protein of the protein tyrosine phosphatase family, is a major autoantigen in insulin-dependent diabetes mellitus. Proc Natl Acad Sci USA 93: 6367-6370

10. Baekkeskov S, Warnock G, Christie M, Rajotte RV, Larsen PM, Fey S (1989) Revelation of specificity of 64 K autoantibodies in IDDM serums by high-resolution 2-D gel electrophoresis. Unambiguous identification of $64 \mathrm{~K}$ target antigen. Diabetes 38: 1133-1141

11. Roep BO, Arden SA, de Vries RRP, Hutton JC (1990) Tcell clones from a type-1 diabetes patient respond to insulin secretory granule proteins. Nature 345: 632-634

12. Pak CY, Cha CY, Rajotte RV, McArthur RG, Yoon JW (1990) Human pancreatic islet cell specific 38 kilodalton autoantigen identified by cytomegalovirus-induced monoclonal islet cell autoantibody. Diabetologia 33: 596-572

13. Honeyman MC, Cram DS, Harrison LC (1993) Transcription factor jun-B is a target of autoreactive T-cells in IDDM. Diabetes 42: 626-630

14. Ko IY, Jun HS, Kim GS, Yoon JW (1994) Studies on autoimmunity for initiation of beta-cell destruction. X. Delayed expression of a membrane-bound islet cell-specific $38 \mathrm{kDa}$ autoantigen that precedes insulitis and diabetes in the diabetes-prone BB rat. Diabetologia 37: 460-465

15. Arden SD, Roep BO, Neophytou PI et al. (1996) Imogen 38:a novel 38-kD islet mitochondrial autoantigen recognized by $\mathrm{T}$ cells from a newly diagnosed type 1 diabetic patient. J Clin Invest 97: 551-561

16. Ko IY, Ihm S, Yoon JW (1991) Studies on autoimmunity for initiation of beta-cell destruction. VIII. Pancreatic beta cell-dependent autoantibody to a 38 kilodalton protein precedes the clinical onset of diabetes in BB rats. Diabetologia 34: $548-554$ 
17. World Health Organization (1985) Diabetes Mellitus: Report of a WHO Study Group. WHO Technical Report Series 727, World Health Organization, Geneva

18. Seidel DK, Geiss HC, Donner MG et al. (1998) Course of islet autoantibody titers during Ig-immunoadsorption in a patient with newly diagnosed type 1 diabetes. J Autoimmun 11: 273-277

19. Efrat S, Linde S, Kofod H et al. (1988) Beta-cell lines derived from transgenic mice expressing a hybrid insulin-oncogene. Proc Natl Acad Sci USA 85: 9037-9041

20. Martinez de la Escalera G, Choi AL, Weiner RI (1990) Generation and synchronization of gonadotropin-releasing hormone $(\mathrm{GnRH})$ pulses: intrinsic properties of the GT1-1 GnRH neuronal cell line. Proc Natl Acad Sci USA 89: 1852-1855

21. Bordier C (1981) Phase separation of integral membrane proteins in Triton X-114 solution. J Biol Chem 256: 1604-1607

22. Ey PL, Prowse SJ, Jenkin CR (1978) Isolation of pure IgG1, IgG2 a and IgG2 b immunoglobulins from mouse serum using protein A-Sepharose. Immunochemistry 15: 429-436

23. Grubin CE, Daniels T, Toivola B et al. (1994) A novel radioligand binding assay to determine diagnostic accuracy of isoform-specific glutamic acid decarboxylase antibodies in childhood IDDM. Diabetologia 37: 433-350

24. Verge CF, Stenger D, Bonifacio E et al (1998) Combined use of autoantibodies (IA-2 autoantibody, GAD autoanti- body, insulin autoantibody, cytoplasmic islet cell antibodies) in type 1 diabetes. Diabetes 47: 1857-1866

25. Elbein AD (1984) Inhibitors of the biosynthesis and processing of N-linked oligosaccharides. CRC Crit Rev Biochem 16: 21-49

26. Schrägger H, von Jagow G (1987) Tricine-sodium dodecyl sulfate-polyacrylamide gel electrophoresis for the separation of proteins in the range from 1 to $10 \mathrm{kDa}$. Anal Biochem 166: 368-379

27. Rademacher TW, Parekh RB, Dwek RA (1988) Glycobiology. Annu Rev Biochem 57: 785-838

28. Wagh PV, Bahl OP (1981) Sugar residues on proteins. CRC Crit Rev Biochem 10: 307-377

29. Batstra MR, Petersen JS, Verwest AM et al. (1998) Autoantibodies to glima 38 , glutamic acid decarboxylase and IA2 in healthy schoolchildren. Diabetes 47[Suppl]:A206 (Abstract)

30. Lennarz WJ (1987) Protein glycosylation in the endoplasmic reticulum. Biochemistry 26: 7205-7210

31. Lan M, Lu J, Goto Y, Notkins AL (1994) Molecular cloning and identification of a receptor-type protein tyrosine phosphatase, IA-2, from human insulinoma. DNA Cell Biol 13: 505-514

32. Lotan R, Nicolson GL (1979) Purification of cell membrane glycoproteins by lectin affinity chromatograph. Biochim Biophys Acta 559: 329-376 